\title{
A Notice
}

CLEPSIDRAS Y HOROLOGIOS MUSULMANES, IN MISCELÁNEA DE ESTUDIOS ÁRABES Y HEBRAICOS, SECCIÓN ÁRABE-ISLAM, vol. 55. By ANTONIO FERNANDEZ-PUERTAS. pp. 135-I85.

The history of Arabic science has produced, during these last decades, some interesting studies from European scholars, such as those of D. A. King, O. Kurz and Juan Vernet, to name only these.

The art historian and Arabist, Antonio Fernández-Puertas, who has devoted brilliant works to Islamic art and notably the Alhambra of Granada, brings his solid contribution to the common task. He rests it on the study of an horologe of the Nasrid period, which can be dated to 764/1362, during the second reign of the sultan of Granada Muhammad V, and which is mentioned in a prose work by the famous fourteenth-century vizier and polygraph, Lisān ad-dīn Ibn al-Khatīb.

Before broaching his detailed examination of this horologe, Antonio Fernández-Puertas widens the field of his profound research with various medieval Muslim clepsydras and horologes. He first shows that the Muslims adopted Greek and Byzantine mechanisms, both for water clocks and automata, for liturgical purposes: that is to say, the respect for the five ritual prayers which were required since the ninth century under the 'Abbāsid dynasty of Baghdād.

In Muslim Spain, the celebrated historian Ibn Hayyān reports that the erudite courtier 'Abbās Ibn Firnās built on horologe (minqāna) which he presented to the Umayyad Emir of Cordova, Muhammad I (238-272/852-886). In the ruins of the palatine city of Madinat azZahrā’, the archeologists Félix Hernāndez Giménez discovered in the I950s some fragmented sun-clocks in the corner of the terrace, their function being to guide the muezzins on the times for the call to prayer. In eleventh-century Toledo, al-Murādī studided in his treatise $3 \mathrm{I}$ models of mechanical horologes, several of which indicated the passage of the hour by the movement of automata. Only one sun clock is indicated.

In the Orient, during the twelfth and thirteenth centuries, three names stand out as authors of treatises on horologes: al-Khazin̄ī, Ridwān and al-Jazarī. Antonio FernándezPuertas analyses their works in an exploratory section, accompanied by various selected and relevant illustrations.

As regards the medieval Maghreb, there is reason to believe that the horologes of Fez and Tlemcen preceded the minkān which is the object of Ibn al-Khatib's description on the occasion of the 764/1362 festivity of the mawlid in the palace of Comares of the Alhambra. The eminent Spanish Arabic scholar Emilio Garcīa Gómez had published an edition and Spanish translation of this passage of the Nufädat al-Jirāb, in his work Foco de antigua luz sobre la Alhambra (Madrid, I988). One of the aims of his book was to make a hypothetical 
reconstruction of the Nasrid minkān of 1362. Antonio Fernández-Puertas returns to the Arabic text, re-translates it in the light of the most recent researches in to Nasrid art and accompanies it with a minute annotation. Basing himself on the text of Ibn al-Khatib, the author presents eight carefully considered drawings and provides a scholarly commentary.

We have greatly appreciated the deep study of our colleague, written in a clear and pure language, accompanied by 25 figures, 70 notes and a solid bibliography that contains, apart from published works in Arabic and Spanish, three titles in German and English.

Rachael Arié

Paris 